\title{
An Investigation of the Attitudes of Sports Media towards Women's Sports
}

\author{
Aliye Menevşe*, Muhammed Emin Ablay \\ School of Physical Education and Sport, Istanbul Esenyurt University, Turkey
}

Copyright $\mathrm{C} 2019$ by authors, all rights reserved. Authors agree that this article remains permanently open access under the terms of the Creative Commons Attribution License 4.0 International License

\begin{abstract}
This study aims to examine the attitudes of sports media employees and sports managers toward women's sports. The research universe includes the sports media employees in Istanbul and academicians in the field of sports while the research sample includes Skorer tv, Fanatik newspaper employees and academicians of Esenyurt University and Istanbul University. Descriptive research model in the research, "Attitudes of Sports Media towards Women's Sports in our Country" survey consists of two sections with 16 items and 28 questions. A total of 161 people were selected by random method $[n=80$ media employees; $(\mathrm{F}=50, \mathrm{M}=30), \mathrm{n}=81$ academicians; $(\mathrm{F}=48$, $M=33)]$ SPSS package program 22 was used in the data statistics and the data were evaluated with frequency, percentage, mean, standard deviation, single factor variance analysis (Oneway ANOVA) at 0.05 level. It was found that female and male sports media employees disagreed with the following two statements with the highest average: "News reports about female athletes are credible and convincing"( $\mathrm{F} ; \overline{\mathrm{x}}=3.9987, \mathrm{M} ; \overline{\mathrm{x}}=4.379)$; "The number of female sports media employees is sufficient in the sports media" (M; $\overline{\mathrm{x}}=3.746, \mathrm{~F} ; \overline{\mathrm{x}}=3.9045)$. It was also found that male sports media employees disagreed with the following two statements with an average higher than that of female sports media employees: "Articles of sports columnists about female athletes are convincing" (M; $\overline{\mathrm{x}}=$ $4.379, \mathrm{~F}$; $\overline{\mathrm{x}}=2.5005$ ); "In our country, there is a Women's sports media which provides professional press services" $(\mathrm{M} ; \overline{\mathrm{x}}=3.113, \mathrm{~F} ; \overline{\mathrm{x}}=2.2798)$. The statement with the highest average (M; $\overline{\mathrm{x}}=3.68)$ of disagreement from the male was "Government makes sufficient use of media instruments to encourage women to start sports" while the statement with the highest average ( $F ; \bar{x}=3.9944)$ of disagreement from the female sports media employees was "Sports media considers demands from readers when determining editorial policy for women's sports". The female participants who participated in our study disagreed with the statements in our survey on "the attitudes of sports media on women's sports" and the statement that "the sources of women's sports and athletes are sufficient" with an average higher than that of male sports media
\end{abstract}

employees.

Keywords Sports Media, University, Women's Sports, News and Comments

\section{Introduction}

Studies on sport and gender relations that began in frame sizes discussions in the 80 s, mostly of bodies working in this field in the sport in the 90s that dealt with research to the position of female identity and the 2000s work which they discussed the masculinity issues in sport. It was observed that the education and sports colleges were carried out by academicians and most of them were descriptive researches which did not include a gender discussion in the critical context. When Turkey Youth and Sports under the Ministry of gender distribution of licensed athletes according to the 60 sports federations of December 2016 records examined, 5 sports federations, except that all sports in male athletes female athletes from more and the total male athlete number $(1,942,204)$ of the number of female athletes (801 174 ) seen to be more than twice [1].

The journal titled "Futbol" that started to be published on September 28, 1910, by Üsküdarlı Mehmet Burhanettin Bey whom Turkish sports and sports press knew by the name of Burhan Felek is one of the important works in the history of sports press. All the articles and photos published in the journal, which is accepted as the pioneer of the Turkish sports press and published half in Turkish and a half in French, belonged to Burhan Felek. Following Burhan Felek's journal "Futbol" that was published for 6 months, in July 1911, Selim Sirrı Tarcan introduced a new journal titled "Terbiye ve Oyun". Terbiye ve Oyun started to be republished in 1922, but after a short time, this initiative failed too. "Jimnastik" and "Riyaziyat-1 Bedeniyye", written in 1891 by Faik Üstünidman, one of the physical education teachers of Galatasaray High School, were among the first of sports articles [2].

The introduction of sports news in printed publications 
begins with the US Boston Newspaper's sending a reporter to the United Kingdom for a boxing match on 5 May 1773 [3]. It is stated that there were 237 sports radio stations broadcasting in the USA as of 1998 [4]. In 1970, the Mexico World Cup was watched in Europe via satellite [5]. Today, on the other hand, professional sports occupy the sports pages of newspapers and sports programs of televisions [6].

The world's first sports channel ESPN, founded in 1978, broadcasts about 7000 hours a year for its 54 million subscribers. ESPN had a significant competitive advantage as the only cable broadcast that broadcasted live 1984 Sarajevo and 1988 Calgary Winter Olympics. After the 1950s, many newspapers in Turkey initiated a separate unit for sports news and started to devote more than one page to sports news. The achievements in the wrestling branch at the Olympics in those years became a factor in the increase of the public interest in the sport [7]. The social pressure created by the heirs of cultural barriers was partly effective in the limited participation of women in sports, both in schools and outside the school. In the West, women's presence in sports, which did not conform to the traditional roles imposed on women, was inhibited especially by educators in schools. One can also encounter such examples in the modernization process.

The acceptance of women in sports competitions is closely related to a society's point of view about women. After long debates in China, a model that envisaged the development of all kinds of sports, both traditional and modern sports, was adopted the first sports laws were issued, stating that both girls and boys should be involved in sports [8]. Many studies have revealed that tabloid magazines, sports newspapers and sports pages of newspapers ignored women or emphasized personal and imaginative illusions about women athletes, expressing their sexual differences by false evidence [9].

As is known, it is considered necessary for each individual to do sports in terms of health; however, the rate of men doing sports is higher than women. Similarly, news and programs devoted to female athletes in the media are considerably less than those devoted to men. One of the main objectives of this study is that the media, which has a significant share in the dissemination of sports and sports branches, ignores organizational, discursive structures and makes publications in accordance with the expectations of women athletes.

\section{Material and Method}

The research covers the internet sports news site of the Milliyet newspaper in Istanbul, sports newspaper and universities, the sample includes Skorer tv, Fanatik newspaper employees and academicians of Esenyurt University and Istanbul University. A total of 161 people were selected by random method $[\mathrm{n}=80$ sports media employees $[(\mathrm{F}=50, \quad \mathrm{M}=30)$ age range: $(20-30=16)$, $(31-40=28),(41-50=26),(50>=10) ; n=81$ sports managers $(\mathrm{F}=48, \mathrm{M}=33)$ age range: $(20-30=0),(31-40=21)$, $(41-50=42),(50>=18)]$. The descriptive research model was employed in the study and the survey method was preferred as the data collection method. The validity and reliability studies of the study were carried out by Cennet Ünal and Abdüsselam Köse: the reliability of the 16 items constituting "Attitudes of Sports Media in Our Country towards Women's Sports" survey was found to be $\alpha=0.964$. The survey employed five-point Likert scale (5-strongly agree, 4-agree, 3-neutral, 2-disagree, 1-strongly disagree).

The data were analysed by using SPSS (Statistical Package for Social Sciences) program. Descriptive statistical methods (frequency, percentage, mean, standard deviation, etc.) were used when evaluating the data and one-way analysis of variance (ANOVA) was used in more than two variables. The significance level was accepted as 0.5 . 


\section{Findings}

Table 1. Means and standard deviation s of scale variables of sports media employees and sports managers by gender

\begin{tabular}{|c|c|c|c|c|c|c|c|}
\hline & & \multicolumn{3}{|c|}{ Sports Media Employees } & \multicolumn{3}{|c|}{ Sports Managers } \\
\hline & Group & $\mathbf{N}$ & Mean & S.D & $\mathbf{N}$ & Mean & S.D \\
\hline \multirow{2}{*}{ Women's sports can find sufficient support in the media. } & Male & 50 & 2,2051 & 1,4175 & 48 & 3,1481 &, 5502 \\
\hline & Female & 30 & 2,3333 & 1,0635 & 33 & 3,0984 & ,4665 \\
\hline \multirow{2}{*}{$\begin{array}{l}\text { Within the scope of social responsibility, the media } \\
\text { provides the necessary support to women's sports. }\end{array}$} & Male & 50 & 2,7468 & 1,1487 & 48 & 3,5309 &, 6141 \\
\hline & Female & 30 & 3,0667 & 1,2172 & 33 & 3,5784 & 1,983 \\
\hline \multirow{2}{*}{ Our country has enough female media managers. } & Male & 50 & 2,8861 & 1,0740 & 48 & 3,6543 & 6549 \\
\hline & Female & 30 & 3,2000 &, 8976 & 33 & 3,7489 & 1,337 \\
\hline \multirow{2}{*}{$\begin{array}{l}\text { There is a broadcast policy in our country that encourages } \\
\text { women to do sports. }\end{array}$} & Male & 50 & 3,2152 & ,9828 & 48 & 3,5185 &, 5939 \\
\hline & Female & 30 & 3,1890 & 1,0755 & 33 & 3,8942 & 1,002 \\
\hline \multirow{2}{*}{ Media policies for women's sports are adequate. } & Male & 50 & 3,4810 & 1,0360 & 48 & 3,5062 &, 5727 \\
\hline & Female & 30 & 2,4600 &, 8304 & 33 & 3,6793 & ,3452 \\
\hline \multirow{2}{*}{$\begin{array}{l}\text { The articles of sports writers about female athletes are } \\
\text { satisfactory. }\end{array}$} & Male & 50 & 4,3797 & ,9910 & 48 & 3,4568 &, 5711 \\
\hline & Female & 30 & 2,5005 &, 8840 & 33 & 3,9000 & ,6633 \\
\hline \multirow{2}{*}{$\begin{array}{l}\text { Media adequately reflects the obstacles in front of } \\
\text { women's doing sports. }\end{array}$} & Male & 50 & 2,4304 & 1,2778 & 48 & 3,3000 & 6037 \\
\hline & Female & 30 & 2,7600 & ,9523 & 33 & 3,6895 & ,3478 \\
\hline \multirow{2}{*}{$\begin{array}{l}\text { The media shows the necessary interest and respect for } \\
\text { women's sports and athletes. }\end{array}$} & Male & 50 & 2,6582 & 1,0363 & 48 & 3,4500 & ,6917 \\
\hline & Female & 30 & 3,1800 & ,8995 & 33 & 3,5674 & $, 1,337$ \\
\hline \multirow{2}{*}{$\begin{array}{l}\text { National female athletes are paid sufficient attention by } \\
\text { the media. }\end{array}$} & Male & 50 & 2,9241 & ,9577 & 48 & 3,6625 &, 6150 \\
\hline & Female & 30 & 2,9300 &, 8583 & 33 & 3,5383 & ,4588 \\
\hline \multirow{2}{*}{$\begin{array}{l}\text { In our country, there is a women's sports media which } \\
\text { provides professional press services. }\end{array}$} & Male & 50 & 3,1139 & 1,0858 & 48 & 3,4875 &, 5952 \\
\hline & Female & 30 & 2,2798 & 1,4290 & 33 & 3,8578 &, 52229 \\
\hline \multirow{2}{*}{$\begin{array}{c}\text { Women's sports events are watched by a sufficient } \\
\text { number of female audiences }\end{array}$} & Male & 50 & 3,2597 & 1,0809 & 48 & 3,5125 &, 5510 \\
\hline & Female & 30 & 2,8900 & 1,1298 & 33 & 3,8833 & ,4599 \\
\hline \multirow{2}{*}{$\begin{array}{l}\text { Sports media takes into account the demands of the reader } \\
\text { when determining broadcast policies for women's sports. }\end{array}$} & Male & 50 & 3,2949 & 9817 & 48 & 3,5125 & ,6363 \\
\hline & Female & 30 & 3,3111 & 1,1108 & 33 & 3,9944 &, 5580 \\
\hline \multirow{2}{*}{$\begin{array}{l}\text { The government makes sufficient use of media } \\
\text { instruments to encourage women to start sports. }\end{array}$} & Male & 50 & 3,4051 & ,9676 & 48 & 3,6875 &, 7043 \\
\hline & Female & 30 & 3,4678 &, 8981 & 33 & 3,7740 &, 5567 \\
\hline \multirow{2}{*}{ Media sources for women's sports are sufficient. } & Male & 50 & 3,6962 & 1,0783 & 48 & 3,4125 & ,6099 \\
\hline & Female & 30 & 3,9874 &, 8989 & 33 & 3,9043 & ,5990 \\
\hline \multirow{2}{*}{$\begin{array}{c}\text { Sports media has a sufficient number of female sports } \\
\text { reporters. }\end{array}$} & Male & 50 & 3,7468 & 1,2451 & 48 & 2,6500 &, 8583 \\
\hline & Female & 30 & 3,9045 & 1,0585 & 33 & 3,8744 & 6744 \\
\hline \multirow{2}{*}{$\begin{array}{l}\text { News reports about female athletes in the media are } \\
\text { credible and convincing. }\end{array}$} & Male & 50 & 4,1392 & 1,1405 & 48 & 3,1625 & ,4623 \\
\hline & Female & 30 & 3,9987 & 1,1939 & 33 & 3,3393 & ,4580 \\
\hline
\end{tabular}

Both Groups responded that they did not participate; in terms of general means, the mean of the disagreement of sports managers was higher than that of sports media employees. 
Table 2. Analysis results of scale variables (\%)

\begin{tabular}{|c|c|c|c|c|c|c|c|c|c|c|c|}
\hline & \multicolumn{6}{|c|}{ Sports Media Employees } & \multicolumn{5}{|c|}{ Sports Managers } \\
\hline & & 1 & 2 & 3 & 4 & 5 & 1 & 2 & 3 & 4 & 5 \\
\hline & & $\%$ & $\%$ & $\%$ & $\%$ & $\%$ & $\%$ & $\%$ & $\%$ & $\%$ & $\%$ \\
\hline \multirow{2}{*}{$\begin{array}{l}\text { Women's sports can find sufficient support in the } \\
\text { media. }\end{array}$} & $\mathrm{F}$ & 35,4 & 20,8 & 14,6 & 20,8 & 12,5 & 8,3 & 2,1 & 68,8 & 18,8 & 2,1 \\
\hline & M & 39,6 & 8,3 & 6,3 & 2,1 & 6,3 & 0,0 & 8,3 & 58,3 & 0,0 & 2,1 \\
\hline \multirow{2}{*}{$\begin{array}{l}\text { Within the scope of social responsibility, the media } \\
\text { provides the necessary support to women's sports. }\end{array}$} & $\mathrm{F}$ & 6,3 & 31,3 & 31,3 & 20,8 & 14,6 & 8,3 & 39,6 & 45,8 & 6,3 & 0,0 \\
\hline & M & 4,2 & 37,5 & 16,7 & 4,2 & 0,0 & 0,0 & 0,0 & 29,2 & 37,5 & 2,1 \\
\hline \multirow{2}{*}{ Our country has enough female media managers. } & $\mathrm{F}$ & 10,4 & 20,8 & 41,7 & 20,8 & 10,4 & 2,1 & 8,3 & 25,8 & 58,3 & 6,3 \\
\hline & M & 0,0 & 25,0 & 16,7 & 12,5 & 8,3 & 0,0 & 0,0 & 20,8 & 47,9 & 0,0 \\
\hline \multirow{2}{*}{$\begin{array}{l}\text { There is a broadcast policy in our country that } \\
\text { encourages women to do sports. }\end{array}$} & $\mathrm{F}$ & 2,1 & 20,8 & 37,5 & 37,5 & 6,3 & 0,0 & 8,3 & 47,9 & 37,5 & 6,3 \\
\hline & $\mathrm{M}$ & 0,0 & 20,8 & 16,7 & 16,7 & 8,3 & 0,0 & 4,2 & 20,8 & 43,8 & 0,0 \\
\hline \multirow{2}{*}{ Media policies for women's sports are adequate. } & $\mathrm{F}$ & 8,3 & 6,3 & 35,4 & 45,8 & 8,3 & 0,0 & 8,3 & 47,9 & 41,7 & 2,1 \\
\hline & $\mathrm{M}$ & 0,0 & 14,6 & 16,7 & 8,3 & 22,9 & 0,0 & 2,1 & 29,2 & 37,5 & 0,0 \\
\hline \multirow{2}{*}{$\begin{array}{l}\text { The articles of sports writers about female athletes are } \\
\text { satisfactory. }\end{array}$} & $\mathrm{F}$ & 6,3 & 2,1 & 29,2 & 10,4 & 56,3 & 0,0 & 8,3 & 43,8 & 43,8 & 4,2 \\
\hline & $\mathrm{M}$ & 0,0 & 2,1 & 10,4 & 0,0 & 50,0 & 0,0 & 43,8 & 20,8 & 4,2 & 0,0 \\
\hline \multirow{2}{*}{$\begin{array}{l}\text { Media adequately reflects the obstacles in front of } \\
\text { women's doing sports. }\end{array}$} & $\mathrm{F}$ & 18,8 & 20,8 & 35,4 & 20,8 & 8,3 & 0,0 & 8,3 & 68,8 & 12,5 & 10,4 \\
\hline & $\mathrm{M}$ & 29,2 & 16,7 & 8,3 & 2,1 & 6,3 & 0,0 & 62,5 & 4,2 & 2,1 & 0,0 \\
\hline \multirow{2}{*}{$\begin{array}{l}\text { The media shows the necessary interest and respect } \\
\text { for women's sports and athletes. }\end{array}$} & $\mathrm{F}$ & 12,5 & 22,9 & 41,7 & 18,8 & 8,3 & 0,0 & 8,3 & 47,9 & 33,3 & 10,4 \\
\hline & $\mathrm{M}$ & 10,4 & 25,0 & 17,6 & 12,5 & 0,0 & 0,0 & 2,1 & 45,8 & 20,8 & 0,0 \\
\hline \multirow{2}{*}{$\begin{array}{l}\text { National female athletes are paid sufficient attention } \\
\text { by the media. }\end{array}$} & $\mathrm{F}$ & 8,3 & 22,9 & 37,5 & 33,3 & 2,1 & 0,0 & 8,3 & 29,2 & 56,3 & 6,3 \\
\hline & $\mathrm{M}$ & 2,1 & 27,1 & 18,8 & 12,5 & 2,1 & 0,0 & 0,0 & 20,8 & 43,8 & 4,2 \\
\hline \multirow{2}{*}{$\begin{array}{l}\text { In our country, there is a women's sports media which } \\
\text { provides professional press services. }\end{array}$} & $\mathrm{F}$ & 12,5 & 12,5 & 35,4 & 31,3 & 12,5 & 0,0 & 8,3 & 39,6 & 50,0 & 2,1 \\
\hline & $\mathrm{M}$ & 0,0 & 31,3 & 8,3 & 18,8 & 4,2 & 0,0 & 47,9 & 20,8 & 0,0 & 0,0 \\
\hline \multirow{2}{*}{$\begin{array}{l}\text { Women's sports events are watched by a sufficient } \\
\text { number of female audiences }\end{array}$} & $\mathrm{F}$ & 6,3 & 8,3 & 43,8 & 20,8 & 25,0 & 0,0 & 8,3 & 2,1 & 43,8 & 45,8 \\
\hline & $\mathrm{M}$ & 6,3 & 18,8 & 16,7 & 12,5 & 8,3 & 0,0 & 0,0 & 29,2 & 37,5 & 2,1 \\
\hline \multirow{2}{*}{$\begin{array}{l}\text { Sports media takes into account the demands of the } \\
\text { reader when determining broadcast policies for } \\
\text { women's sports. }\end{array}$} & $\mathrm{F}$ & 2,1 & 14,6 & 35,4 & 39,6 & 12,5 & 0,0 & 8,3 & 47,9 & 35,4 & 8,3 \\
\hline & $\mathrm{M}$ & 2,1 & 14,6 & 27,1 & 18,8 & 0,0 & 2,1 & 0,0 & 29,2 & 37,5 & 0,0 \\
\hline \multirow{2}{*}{$\begin{array}{l}\text { The government makes sufficient use of media } \\
\text { instruments to encourage women to start sports. }\end{array}$} & $\mathrm{F}$ & 8,3 & 8,3 & 35,4 & 35,4 & 16,7 & 0,0 & 8,3 & 31,3 & 47,9 & 12,5 \\
\hline & $\mathrm{M}$ & 0,0 & 6,3 & 20,8 & 20,8 & 14,6 & 2,1 & 2,1 & 20,8 & 43,8 & 0,0 \\
\hline \multirow{2}{*}{ Media sources for women's sports are sufficient. } & $\mathrm{F}$ & 4,2 & 14,6 & 25,0 & 31,3 & 29,2 & 8,3 & 6,3 & 47,9 & 35,4 & 2,1 \\
\hline & $\mathrm{M}$ & 0,0 & 2,1 & 22,9 & 18,8 & 18,8 & 0,0 & 0,0 & 41,7 & 25,0 & 2,1 \\
\hline \multirow{2}{*}{$\begin{array}{l}\text { Sports media has a sufficient number of female sports } \\
\text { reporters. }\end{array}$} & $\mathrm{F}$ & 16,7 & 8,3 & 14,6 & 37,5 & 27,1 & 8,3 & 37,5 & 37,5 & 14,6 & 2,1 \\
\hline & M & 10,4 & 25,0 & 17,6 & 12,5 & 0,0 & 0,0 & 20,8 & 33,3 & 14,6 & 0,0 \\
\hline \multirow[t]{2}{*}{$\begin{array}{l}\text { News reports about female athletes in the media are } \\
\text { credible and convincing. }\end{array}$} & $\mathrm{F}$ & 8,3 & 12,5 & 22,9 & 16,7 & 43,8 & 8,3 & 2,1 & 79,2 & 8,3 & 2,1 \\
\hline & M & 0,0 & 2,1 & 8,3 & 12,5 & 39,6 & 0,0 & 0,0 & 47,9 & 20,8 & 0,0 \\
\hline
\end{tabular}

1; strongly agree 2; agree, 3; neutral, 4; disagree, 5 ; strongly disagree

When the scale variables of the female sports media employees are analysed, they responded to 12 questions as neutral, strongly disagree or disagree (Total percent $/ 12=$ $83.18 \%)$.

When the scale variables of the male sports media employees are analysed, they responded to 9 questions as neutral and agree (Total percent / $9=49.32 \%$ ) whereas they responded to 7 questions as neutral and disagree
(Total percent $/ 7=53.28 \%$ ).

When the scale variables of the male sports managers are analysed, they responded to 11 questions as neutral and disagree (Total percent $/ 11=67.61 \%$ ).

When the scales variables of the female sports managers are analysed, they responded to 13 questions as neutral and disagree (Total percent $/ 13=90.97 \%$ ). 
Table 3. The comparison of the scale of “Attitudes of Sports Media in Our Country towards Women's Sports" with the variables of the frequency of doing sports, watching women's sports events, and follow-up of sports and comments about women's sports events and women's sports

\begin{tabular}{|c|c|c|c|c|c|c|c|c|}
\hline Sports Media Employees & & Group & $\bar{X}$ & $\begin{array}{c}\text { Sum of } \\
\text { Squares }\end{array}$ & df & $\begin{array}{l}\text { Mean of } \\
\text { Squares }\end{array}$ & $\mathbf{F}$ & $\mathbf{p}$ \\
\hline \multirow{3}{*}{ Frequency of doing sports } & \multirow{3}{*}{$\begin{array}{l}\text { Inter-groups } \\
\text { Intra-groups } \\
\quad \text { Total }\end{array}$} & Never & 1,2056 & 18,034 & 40 &, 451 & \multirow{3}{*}{1,690} & \multirow{3}{*}{$\begin{array}{l}016^{*} \\
\text { II -I }\end{array}$} \\
\hline & & Occasionally & 2,5120 & 31,741 & 119 &, 267 & & \\
\hline & & Always & 1,8084 & 49,775 & 159 & & & \\
\hline \multirow{4}{*}{$\begin{array}{l}\text { Watching women's sports } \\
\text { events }\end{array}$} & \multirow{4}{*}{$\begin{array}{l}\text { Inter-groups } \\
\text { Intra-groups } \\
\quad \text { Total }\end{array}$} & Agree & 1,0180 & 36,768 & 40 & ,919 & \multirow{4}{*}{2,040} & \multirow{4}{*}{$\begin{array}{l}, 002^{*} \\
\text { III-IV }\end{array}$} \\
\hline & & Disagree & 1,9241 & 53,632 & 119 &, 451 & & \\
\hline & & Partly & 3,6482 & \multirow{2}{*}{90,400} & \multirow{2}{*}{159} & & & \\
\hline & & Always & 1,0051 & & & & & \\
\hline \multirow{4}{*}{$\begin{array}{l}\text { Follow-up of news and } \\
\text { comments about female } \\
\text { sports }\end{array}$} & \multirow{4}{*}{$\begin{array}{l}\text { Inter-groups } \\
\text { Intra-groups } \\
\quad \text { Total }\end{array}$} & Agree & 1,0178 & 39,902 & 40 & ,998 & \multirow{4}{*}{2,217} & \multirow{4}{*}{$\begin{array}{l}, 001^{*} \\
\text { III-I }\end{array}$} \\
\hline & & Disagree & 1,3041 & 53,541 & 119 &, 450 & & \\
\hline & & Disagree & 3,2949 & \multirow{2}{*}{93,444} & \multirow{2}{*}{159} & & & \\
\hline & & Always & 1,4250 & & & & & \\
\hline Sports Managers & & Group & $\bar{X}$ & $\begin{array}{c}\text { Sum of } \\
\text { Squares }\end{array}$ & df & $\begin{array}{l}\text { Mean of } \\
\text { Squares }\end{array}$ & $\mathbf{F}$ & $\mathbf{p}$ \\
\hline \multirow{3}{*}{ Frequency of doing sports } & \multirow{3}{*}{$\begin{array}{c}\text { Inter-groups } \\
\text { Intra-groups } \\
\text { Total }\end{array}$} & Never & 1,3046 & 19,031 & 40 &, 514 & \multirow{3}{*}{1,750} & \multirow{3}{*}{$\begin{array}{l}, 023^{*} \\
\text { II-III }\end{array}$} \\
\hline & & Occasionally & 2,9120 & 36,471 & 119 & ,767 & & \\
\hline & & Always & 1,1081 & 48,577 & 159 & & & \\
\hline \multirow{4}{*}{$\begin{array}{l}\text { Watching women's sports } \\
\text { events }\end{array}$} & \multirow{4}{*}{$\begin{array}{l}\text { Inter-groups } \\
\text { Intra-groups } \\
\quad \text { Total }\end{array}$} & Agree & 2,0182 & 33,867 & 40 &, 817 & \multirow{4}{*}{2,031} & \multirow{4}{*}{$\begin{array}{l}, 001^{*} \\
\text { III-IV }\end{array}$} \\
\hline & & Disagree & 2,3241 & 51,232 & 119 &, 541 & & \\
\hline & & Partly & 3,5364 & \multirow{2}{*}{90,004} & \multirow{2}{*}{159} & & & \\
\hline & & Always & 2,0123 & & & & & \\
\hline \multirow{4}{*}{$\begin{array}{c}\text { Follow-up of news and } \\
\text { comments about female } \\
\text { sports }\end{array}$} & \multirow{4}{*}{$\begin{array}{l}\text { Inter-groups } \\
\text { Intra-groups } \\
\quad \text { Total }\end{array}$} & Agree & 2,0187 & 36,209 & 40 & ,899 & \multirow{4}{*}{2,712} & \multirow{4}{*}{$\begin{array}{l}, 000^{*} \\
\text { III-II }\end{array}$} \\
\hline & & Disagree & 1,2150 & 56,145 & 119 &, 580 & & \\
\hline & & Partly & 3,3681 & \multirow{2}{*}{91,159} & \multirow{2}{*}{159} & & & \\
\hline & & Always & 1,2405 & & & & & \\
\hline
\end{tabular}

$\mathrm{p}<, 05$ significance level

A significant difference was found between the sports media employees' mean scores of the survey "attitudes of sports media towards women's sports" and group means of the variable of "frequency of doing sports" ( $\mathrm{F}=1.69$, $\mathrm{p}=0.016<0.05)$. A significant difference was found between the sports media employees' mean scores of the survey "attitudes of sports media towards women's sports" and group means of the variable of "watching women's sports events" $(\mathrm{F}=2.040, \mathrm{p}=0.002<0.05)$. A significant difference was found between the sports media employees' mean scores of the survey "attitudes of sports media towards women's sports" and group means of the variable of "follow-up of news and comments about women's sports" $(\mathrm{F}=2.217, \mathrm{p}=0.001<0.05)$.

A significant difference was found between the sports managers' mean scores of the survey "attitudes of sports media towards women's sports" and means of the variable of "frequency of doing sports" $(\mathrm{F}=1.750, \mathrm{p}=0.023<0.05)$. A significant difference was found between the sports managers' mean scores of the survey "attitudes of sports media towards women's sports" and means of the variable of "watching women's sports events" (F=2.031, $\mathrm{p}=0.001<0.05)$. A significant difference was found between the sports managers' mean scores of the survey "attitudes of sports media towards women's sports" and means of the variable of "follow-up of news and comments about women's sports" ( $\mathrm{F}=2.712, \mathrm{p}=0.000<0.05)$.

\section{Discussion}

This study was conducted to examine the opinions of sports media employees and sports managers in universities about the "attitudes of sports media in our country towards women's sports". Of all the sports media employees who participated in the research, $18(22.5 \%)$ never do sports, 39 (48.8\%) occasionally do sports and 23 (28.7) often do sports. The research sample generally consists of media employees who occasionally do sports. It was found out that while 15 (18.8) of sports media employees watch women's sports events, 24 (30\%) do not watch women's sports events. $34(42.5 \%)$ stated that they watch these events only at times while $7(8.8 \%)$ stated that they always watch these events. Therefore, we can generally say that sports media employees included in the research sample follow women's sports events at times. 
Therefore, the need emerges for the media to take into account the potential of the female audience interested in sports and to pay more attention to women's sports. Of the sports media employees who participated in the research, $15(18.8 \%)$ follow the news and comments about women's sports while $20(25 \%)$ do not. $37(46.3 \%)$ stated that they followed such events only at times while $8(10 \%)$ always followed. Therefore, we can generally say that sports media employees included in the research sample follow the news and comments about women's sports only at times.

Of the sports managers who participated in the research, $4(25 \%)$ never do sports, $71(87.7 \%)$ occasionally do sports and $6(7.4 \%)$ often do sports. The research sample generally consists of academicians who occasionally do sports.

Of the sports managers who participated in the research, $2(2.5 \%)$ stated that they watch women's sports events, 8 $(9.9 \%)$ stated that they do not watch women's sports events. $67(82.7)$ stated that they watch these events at times while $4(4.9 \%)$ of them stated that they always watch them. We can conclude that the academicians in the research sample follow women's sports events. Of the sports managers who participated in the research, $3(3.7 \%)$ follow the news and comments about women's sports, $8(9.9 \%)$ do not follow, $66(81.5 \%)$ follow at times while $4(4.9 \%)$ always follow the news and comments about women's sports. We can conclude that the academicians in the research sample follow the news and comments about women's sports at times.

Considering the opinions of sports media employees regarding the scale questions according to gender, we can see that female employee generally responded as "strongly disagree" or "disagree". The responses of female and male sports media employees indicate that they disagreed with the following two statements with the highest average: "News reports about female athletes are credible and convincing" ( $\mathrm{F} ; \overline{\mathrm{x}}=3.9987, \mathrm{M} ; \overline{\mathrm{x}}=4.379)$; "The number of female sports media employees is sufficient in the sports media" (M; $\overline{\mathrm{x}}=3.746, \mathrm{~F} ; \overline{\mathrm{x}}=3.9045)$.

It was also found that female participants disagreed with the scale variables more than male participants. Male sports media employees, on the other hand, disagreed with the following two statements with an average higher than that of female sports media employees: "Articles of sports columnists about female athletes are convincing" (M; $\bar{x}=$ $4.379, F ; \quad \bar{x}=2.5005$ ); and "In our country, there is a women's sports media which provides professional press services" (M; $\bar{x}=3.113, F ; \bar{x}=2.2798)$.

Considering the opinions of sports managers regarding the scale questions according to gender, we can see that female sports managers generally responded as "strongly disagree" or "disagree". The responses indicate that the male sports managers disagreed with the statement "Government makes sufficient use of media instruments to encourage women to start sports" with the highest value of mean $(\mathrm{M} ; \overline{\mathrm{x}}=3,68)$. On the other hand, the male sports managers disagreed with the statement "Sports media takes into account the demands of the reader when determining broadcast policies for female sports." with the highest value of mean ( $F ; \bar{x}=3,9944)$.

When the responses of female sports media employees to scale variables are examined, their responses to 12 questions (Total percent $/ 12=83.18 \%$ ) are neutral, strongly disagree and disagree. On the other hand, when the responses of male sports media employees to scale variables are examined, their responses to 9 questions (Total percent/ $9=49.32 \%$ ) are neutral and agree while their responses 7 questions are (Total percent $/ 7=53.28 \%$ ) are neutral and disagree.

When the responses of male sports managers to scale variables are examined, their responses to 11 questions (Total percent $/ 11=67.61 \%$ ) are neutral and disagree. On the other hand, when the responses of female sports managers to scale variables are examined, their responses to 13 questions (Total percent $/ 13=90.97 \%$ ) are neutral and disagree.

A significant difference was found between the responses of sports media employees' to the following variables of "attitudes of sports media in our country towards women's sports": "frequency of doing sports" ["occasionally" ( $\bar{x}=2.5120, \mathrm{~F}=1.69, \mathrm{p}=0.016<0.05)]$, "watching women's sports events" ["at times" ( $\bar{x}=3.6482$, $\mathrm{F}=2,040, \mathrm{p}=0.002<0.05)]$ and "follow-up of news and comments about women's sports ["at times" $(\overline{\mathrm{x}}=3.2949, \mathrm{~F}$ $=2.217, \mathrm{p}=0.001<0.05)]$.

A significant difference was found between the responses of sports managers' to the following variables of "attitudes of sports media in our country towards women's sports": "frequency of doing sports" [ "occasionally" $(\overline{\mathrm{x}}=$ 2.9120, $\mathrm{F}=1,750, \mathrm{p}=0.023<0.05)]$, "watching women's sports events" ["at times" ( $\overline{\mathrm{x}}=3.5364, \mathrm{~F}=2,031$, $\mathrm{p}=0.001<0.05)]$ and "follow-up of news and comments about women's sports ["at times" ( $\bar{x}=3.3681, F=2.712$, $\mathrm{p}=0.000<0.05)]$.

According to the research on Television Watching Tendencies carried out by RTUK (the Supreme Board of Radio and Television), the distribution of frequency of watching television programs in Turkey according to socio-economic indicators show that of all the viewers of the sports programs, $71.4 \%$ are male and $14 \%$ are female [10].

A study investigating the effect of media on females [11], revealed that only $0.9 \%$ of the females participating in the study read the sports pages in the newspapers. Similarly, the same study found that $89 \%$ of the participants never watched sports programs on television, $10.9 \%$ occasionally, and $6.2 \%$ always. Our study also found similar results. According to [12], study, $114(\% 28.50)$ of the individuals who participated in the study stated that they followed news and comments about women's sports, 192 (48\%) stated they followed only at times, 94 (23.50\%) stated they 
did not follow. In our study, on the other hand, it was found that $82.7 \%$ of the sports managers stated that they followed women's sports events only at times while $42.5 \%$ of sports media employees stated that they followed at times and 30\% of them stated they did not watch.

A study on the reasons why female sports are not included in the media carried out with 285 sports editors in the USA found out that most editors fail to research about readers' curiosity while also most of them believe that the sporting potential of the females is low compared to the males [13]. According to the same study, 27\% of female newspaper readers and $58 \%$ of male newspaper readers stated they regularly read sports pages. Our study, on the other hand, revealed that sports media employees disagreed with the statement that media pays sufficient attention to women's sports with a mean of $\bar{x}=2,658$ and sports managers disagreed with the same statement with a mean of $\bar{x}=3,450$. A research [14], on 3 newspapers published across Turkey reported that $8.56 \%$ of sports news in newspapers are about female athletes, $79.98 \%$ are about male athletes while $11.46 \%$ are about both male and female athletes and the news were in accordance with the social roles imposed on genders. Author [15], argues that female athletes who achieve success in Turkey cannot become popular because they cannot find a place in the media.

In addition to the fact that the media devotes little space to female athletes, the way in which news about females is presented is also important. In a study on how athletes are represented in Turkish printed media in the case of national athlete Süreyya Ayhan [16], it was determined that the success of females in sports was reported as extraordinary and random situations in the press and the definitions and information about being a female were presented even before the identity of the athlete.

The results of the study on "Women in Sports Media in the Context of Gender" are as follows: the number of sports news about females is less than the number of sports news about males; the news about female athletes and about male athletes also differ in terms of sports branches sports media mostly covers news about "football" and about "male athletes" [17].

The results of [12] study on "Effect of Local Media and Media on the Development of Female Athletes in Our Country and Expectations of Female Athletes from Media": the sports media in Turkey has a low level of attitude towards female sports; neither television nor newspapers devote sufficient time/ space to the achievements/failures of female athletes; athlete identities of female athletes are pushed into the background and they are shown as if they are movie stars or beauty queens. A study on the perception of Turkish society on sports media [18], reported that $61 \%$ of males and $18 \%$ of females read sports pages regularly. According to Football Public Opinion Survey [19], 56.7\% of males and $14.6 \%$ of females always watched the news and comments about football. $75 \%$ of the females said they occasionally watched news and comments on football. It was also found that the increase in the number of women in sports media was found odd by the male sports employees and readers at first but later, they started to accept the situation. Female sports journalists stated that in the early days of their employment, their sports service managers expected them to reflect the sports events through a female perspective, but later knowledge and the power of interpretation prevailed over gender [20].

When we look at the organizational and discursive structures of sports media; August 29, 2009 Sabah newspaper, weight of the weightlifting athlete Ayşegül Çoban's success in the title of the news about the success of the exclamation (This girl was talented!). And the news entry bas thinking that the talent would not be successful at the beginning of the first weight that no one believes Ayşegül Çoban, astonishing European Junior Weightlifting Championship has been the winner of the championship başarı with the statement that the success of the female athlete in the field has been confirmed. In the same way, the national boxer Gülsüm Tatar won the championship" Altın Kız Gülsüm. August 26, 2009 in the evening newspaper, 'ada Here is the inside of us! M' 'Ac Gülle and the women in the discus throw, the Turkish men passed. In the spotlight between men and women athletes, it is seen as temsil tragicomic Eş a situation where men and women athletes are left behind. News headlines are important in terms of showing the dominant ideology contained in the text and determining the perspective of the reader to the text [1].

According to these results, the two groups of participants participating in the study follow the women's sports events and the news and comments related to female sports only at times. This situation can be interpreted as little interest in female sports, a small number of female athletes and most importantly, little coverage about women's sports in the media. A number of studies have reported results that support the fact that magazinish media's point of view towards women is mostly about women's social life and standards and this media regards women as an element to get a rating, which prevails over females' sports achievements.

\section{REFERENCES}

[1] E.K. Duru, Sexism In Sports And Representation Of Female Athletes In News Texts, İnternational Peer-Revieed Journal Of Communication And Humanities Research January/ February/ March- Winter Semester Issue: 14 Year: 2016, Gel Code: Y90-Z19 ID:351, K:411

[2] E. Hiçyilmaz, Türkiye'de Spor Gazeteciliği ve Haberciliğinin Tarihi, Spor Basını ve Basında Spor, Hürriyet Vakfı Eğitim Yayınları, No: 7, 7. Seminer Tutanakları içinde. 11-12, 15, 1985.

[3] W. Nichols, Media Rlations in Sport. Sport Management 
Library. Morgantown: Fitness Information Technology 219,2008 Inc.4, 17, 2002.

[4] S. Özsoy, Y. Eskicioğlu, Türkiye' de Spor Medyasında Etik, Kocaeli Üniversitesi İletişim Fakültesi Araştırma Dergisi, Y1l: 5, Say1: 9, ss. 45-64, 2007.

[5] C. Mcgill, Futbolun Kârhanesi Futbol Taraftarlarının Elinden Nasıl Kayıyor? (Çeviren: Can Cemgil), İthaki Yayınları, İstanbul, 113-114, 2006

[6] N. Mirzeoğlu, Spor Bilimlerine Giriş. Bağırgan Yayınevi, Ankara, 3, 66, 87, 93: 16, 2003

[7] A. Atalay, Spor, Medya ve Serbest Zaman, Beta Yayınevi, İstanbul,: 91, 112, 158, 2004.

[8] F. Hong, T. Hua, Sports in China: Conflict Between Tradition and Modernity, 1840s to 1930, s. Ed.: Mangan J. A. ve Hong F., Sports in Asian Society Past and Present. Frank Cass Publisher, London. 189-212, 2003

[9] S. Lynn, M. Hardin, K. Walsdorf, Selling (out) the Sporting Woman: Advertising Images in Four Athletic Magazines. Florida State Uni. \& Penn State Uni. Journal of Sport Management. Human Kinetics Publishers, Vol.18, 335-349, 2004.

[10] Radyo Televizyon Üst Kurulu, Televizyon İzleme Eğilimleri Araştırması - 2, Ankara: RTÜK Kamuoyu Yayın Araştırmaları ve Dairesi Başkanlığı. 2009.

[11] N. Koparan, Medyanın Kadınlar Üzerindeki Etkisi. Yayınlanmamış Doktora Tezi. Gazi Üniversitesi. Eğitim Bilimleri Enstitüsü, 2007.

[12] C. ÜNAL, Ülkemizde Kadın Sporcuların Gelișiminde Yerel Basın ve Medyanın Etkisi İle Kadın Sporcuların Medyadan Beklentileri, Erciyes Üniversitesi, Yüksek Lisans Tezi, 2013.

[13] M. Hardin, Survey Finds Boosterism, Freebies Remain Problem For Newspaper Sports Departments. Newspaper Research Journal, Vol.26, No. 1, 66-72.2005.

[14] B. Arslan, C. Koca, Kadın Sporcuların Yer Aldığı Günlük Gazete Haberlerinin Sunum Biçimine Dair Bir İnceleme. Hacettepe Spor Bilimleri Dergisi, Vol.17, No.1, 1-10, 2006.

[15] V. Kanetti, Koş Süreyya Koş, Şampiyon Olacağız. İstanbul: Gendaş Yayınları, 2001.

[16] M.G. Öktem, Sporcu Kadının Türk Yazılı Basınındaki Temsili: Süreyya Ayhan Örneği. Kadın Çalışmalarında Disiplinlerarası Buluşma Sempozyumu Kitabı. 3, 164-176, 2004.

[17] C. Akkaya., Y. Kaplan. Toplumsal Cinsiyet Bağlamında Spor Medyasında Kadın International Journal of Science Culture and Sport August 2014 : Special Issue 2 ISSN : 2148-1148 Doi : 10.14486/IJSCS189

[18] Y. Taşmektepligil, Perception of Turkish media by Turkish society. The 46th Ichper SD Anniversary World Congress Book. 541-545., 2005.

[19] Türkiye Futbol Federasyonu. Futbol Kamuoyu Araştırması. İstanbul: Türkiye Futbol Federasyonu Yayın1, 2005

[20] S. Özsoy, Türk Spor Medyasında Kadın, Spor Bilimleri Dergisi, Hacettepe J. of Sport Sciences, Vol.19, No.4, 201- 